\title{
Comparison of the Wild-Type Obligate Methylotrophic Bacterium Methylophilus quaylei and its Isogenic Streptomycin-Resistant Mutant via Metal Nanoparticle Generation
}

\author{
Vladimir V. Sorokin $^{1} \cdot$ Anna B. Pshenichnikova ${ }^{2} \cdot$ Sergei V. Kalenov $^{3}$ (D) Nikolay A. Suyasov ${ }^{3} \cdot$ Dmitry A. Skladnev $^{1}$
}

Received: 12 March 2019 / Accepted: 22 April 2019/Published online: 9 May 2019

(C) The Author(s) 2019

\begin{abstract}
Metal nanoparticles synthesized by green methods with the use of microorganisms are currently one of the most closely studied types of nanomaterials. It has accurately been shown that the characteristics of metal nanoparticles generated in the presence of different bacteria vary. For the two isogenic strains of obligate methylotrophic bacteria of the wild type $\left(M\right.$. quaylei $\left.\mathrm{MT}^{\mathrm{T}}\right)$ and its streptomycin-resistant mutant (M. quaylei $\left.\mathrm{SM}^{\mathrm{R}}\right)$, the pleiotropic character of streptomycin resistance mutation in the $\mathrm{SM}^{\mathrm{R}}$ cells has been revealed. It has been shown that both cultures can generate silver nanoparticles. There is a dramatic difference in the formation of palladium nanoparticles, which are formed only in the presence of cells of the streptomycin-resistant mutant M. quaylei $\mathrm{SM}^{\mathrm{R}}$. This study shows that closely related isogenic strains of obligate methylotrophic bacteria can be distinguished by the spectra of biogenic nanoparticles of two noble metals. While palladium nanoparticles are only generated by the cells of the streptomycin-resistant mutant M. quaylei $\mathrm{SM}^{\mathrm{R}}$, biogenic silver nanoparticles can be generated from both cultures. Thus, the assessment of the ability of microorganisms to form biogenic nanoparticles of different metals allows the revelation of subtle metabolic differences of even close cultures.
\end{abstract}

Keywords Silver nanoparticles $\cdot$ Palladium nanoparticles $\cdot$ Methylotrophic bacterium $\cdot$ Biogenic nanoparticles

\begin{tabular}{|c|c|}
\hline \multicolumn{2}{|c|}{ Abbreviations } \\
\hline NPs & Nanoparticles \\
\hline $\mathrm{Ag}^{\circ} \mathrm{NPs}$ & Silver nanoparticles \\
\hline $\mathrm{Pd}^{\circ} \mathrm{NPs}$ & Palladium nanoparticles \\
\hline DBNG & Detection of biogenic nanoparticles generation \\
\hline PQQ & Pyrroloquinoline quinone \\
\hline EDTA & Ethylenediaminetetraacetic acid \\
\hline CFU & Colony forming unit \\
\hline EPS & Exopolysaccharides \\
\hline
\end{tabular}

Sergei V. Kalenov

wsezart@yandex.ru; wsezart@gmail.com

1 Winogradsky Institute of Microbiology, Research Center of Biotechnology of the Russian Academy of Sciences, 33, Bld. 2 Leninsky Ave., Moscow, Russia

2 Department of Biotechnology and Industrial Pharmacy, MIREA Russian Technological University, 86 Vernadsky Avenue, Moscow, Russia

3 Department of Biotechnology, Faculty of Biotechnology and Industrial Ecology, D.I. Mendeleyev University of Chemical Technology of Russia, 9 Miusskaya Square, Moscow, Russia

\section{Introduction}

Methylotrophic bacteria are well known as objects of various biochemical and biotechnological studies [1-4] but not as producers of biogenic metal nanoparticles. At the same time, gram-negative aerobic methylotrophic bacteria have prospects for use in nanobiotechnology for the biogenic synthesis of metal nanoparticles. Obligate methylotrophic microorganisms are non-pathogenic because they can not receive the sole carbon and energy source for growth in a mammalian organism and it's important for production purposes. Perhaps that is why methylotrophic microorganisms have been considered as industrial, biotechnological objects in the past few decades [5-8]. The high growth rate, the low price of growth media with methanol, and the plasticity of the regulation of growth parameters make it possible to consider methylotrophs as promising universal producers.

Methylotrophic cells can use soluble periplasmic methanol dehydrogenase, which is an enzyme containing the prosthetic pyrroloquinoline quinone (PQQ) group. The methanol dehydrogenase of methylotrophs catalyzes the first reaction in an unusual periplasmic electron transport chain responsible for the oxidation of methanol to formaldehyde, utilizing the 
mechanism of the direct transfer of a hydride ion from the methyl group of methanol to PQQ [1]. Alternative electron acceptors in such a chain can be cations that are present in the medium, which are the source material for the formation of nanoparticles of the corresponding metals [9-12].

In cases of excessive content of toxic cations in the medium, the formation of nanoparticles from reduced atoms as a less toxic product is observed as a natural protective reaction of microbial cells [13-15]. It is believed that the ability to form nanoparticles of metals from sterile salt solutions artificially introduced into cell suspensions can be considered to be a complex characteristic of the natural ability of the microorganisms for self-preservation $[16,17]$. The possibility of using the process of the formation of biogenic silver nanoparticles for a comparative integral evaluation of the biological properties of microorganisms was first shown by the example of different microbial communities in the horizons of the Antarctic subglacial Lake Untersee [18]. In all the samples studied, the formation of $\mathrm{Ag}^{\circ} \mathrm{NPs}$ from an artificially introduced sterile silver salt solution occurred only in the presence of microbial cells. In the control analogs, specifically in the corresponding water samples that were released from the bacterial cells, the generation of nanoparticles was not observed because of the absence of cation reductants in the oligotrophic medium of the samples. The authors named this method of studying the cells of microorganisms the DBNG (detection of biogenic nanoparticles generation) $[18,19]$.

It has been proposed to use the ability of microorganisms to generate metal nanoparticles from reduced cations as an indicator of the presence of metabolically active cells in test samples [19]. Since it is known that the external components of microbial cells play the primary role in the recovery of cations [20-23], this study compared the ability of closely related analogs of cultures of microorganisms that differ in the characteristics of the surface structures of their cells to generate biogenic nanoparticles of noble metals.

To compare closely related microorganisms using the DBNG method, a widely used approach in genetics was chosen. The approach consists of a comparative analysis of an isogenic pair of cultures. One of the cultures differs from the other in that it contains a single additional mutation leading to some change in the properties of the original culture. In this study, the DBNG method used the cells of an isogenic pair of the obligate methylotrophic bacterium M. quaylei, the wild type, and an isogenic streptomycin-resistant mutant, to compare the ability to form biogenic nanoparticles. Previously, the ability to compare an isogenic pair of cultures to synthesize metal nanoparticles had never been the subject of nanobiotechnological research.

It should be noted that, similar to the oligotrophic microorganisms of Lake Untersee, the cultures of the obligate methylotroph $M$. quaylei require simple synthetic media for growth that do not contain high-molecular-weight organic compounds that can participate in the chemical reduction of silver cations during the formation of nanoparticles. The absence of abiogenic reductants makes it possible to more accurately assess the details of the interaction of the salts with the cells of closely related methylotrophic bacteria.

\section{Materials and Methods}

\section{The Cultures of the Microorganisms}

The obligate methylotrophic bacteria deposited in the allRussian collection of microorganisms (VKM), specifically, M. quaylei (VKM B-2338) of the wild type [24] and its isogenic streptomycin-resistant $\mathrm{SM}^{\mathrm{R}}$ mutant, were used.

The genetic characterization of the cultures of an isogenic pair of obligate methylotrophic M. quaylei strains was conducted using a standard sequence analysis of their 16S rRNA genes [25].

\section{Cultivation of $M$. quaylei}

The methylotrophic cultures were grown on MQ medium, including a mineral source of nitrogen and phosphates to stabilize the $\mathrm{pH}$ level, with the following composition $\left(\mathrm{g} \mathrm{L}^{-1}\right)$ : $\mathrm{K}_{2} \mathrm{HPO}_{4} 1.5, \mathrm{KH}_{2} \mathrm{PO}_{4} 0.7, \mathrm{NaNO}_{3} 1, \mathrm{MgSO}_{4} \times 7 \mathrm{H}_{2} \mathrm{O} \quad 0.2$, and $\mathrm{CaCl}_{2}$ 0.02. Two milliliters of trace element solution was added separately and contained (mg $100 \mathrm{~mL}^{-1}$ ) $\mathrm{FeSO}_{4} \times 7 \mathrm{H}_{2} \mathrm{O}$ $100, \mathrm{ZnSO}_{4} \times 7 \mathrm{H}_{2} \mathrm{O} 5, \mathrm{MgCl}_{2} \times 4 \mathrm{H}_{2} \mathrm{O} 1.5, \mathrm{CoCl}_{2} \times 6 \mathrm{H}_{2} \mathrm{O} 10$, $\mathrm{CuCl}_{2} \times 5 \mathrm{H}_{2} \mathrm{O} 5, \mathrm{NiCl}_{2} \times 6 \mathrm{H}_{2} \mathrm{O} 1, \mathrm{Na}_{2} \mathrm{MoO}_{4} 1.5$, and EDTA 250. The components were sterilized in solution at $121^{\circ} \mathrm{C}$ for $25 \mathrm{~min}$. The phosphates and trace element solutions were sterilized separately. All the solutions cooled quickly and were mixed with the trace element solution and methanol $(0.5 \%, v / v)$ as the sole carbon and energy source under sterile conditions.

Cultivation was carried out at $28{ }^{\circ} \mathrm{C}$ and $180 \mathrm{rpm}$ using a Unimax 2010 orbital platform shaker (Heidolph, Germany) within 3 days. The volume of the media was $50 \mathrm{~mL}$, with cultivation in $250 \mathrm{~mL}$ conical flasks. Experiments of the NP generation and sensitivity of bacteria to silver and palladium salts were conducted using cultures in the exponential phase at $9 \times 10^{8} \mathrm{CFU} / \mathrm{ml}$.

\section{乙-Potential Measurement}

Measurement of cell surface $\zeta$-potential was performed with a Delsa Nano Submicron Particle Size Analyzer (Beckman Coulter Inc., USA) that uses electrophoretic light scattering for the $\zeta$-potential determination with the cells which are washed and placed in a buffer of a predetermined ionic strength and $\mathrm{pH}$ value. 


\section{Materials}

As the source of ionic silver, an aqueous solution of $\mathrm{Ag}\left(\mathrm{NH}_{3}\right)_{2} \mathrm{NO}_{3}$ synthesized from $\mathrm{AgNO}_{3}$ and ammonia according to a modified Tollens protocol was used to form the $\mathrm{Ag}^{\circ} \mathrm{NPs}[19,26]$. The sterile $\mathrm{Ag}\left(\mathrm{NH}_{3}\right)_{2} \mathrm{NO}_{3}$ solution was added directly to the samples to achieve a final concentration of $0.1 \mathrm{mM}$.

The source of the palladium ions for the formation of $\mathrm{Pd}^{\circ} \mathrm{NPs}$ was an aqueous solution of $\mathrm{Na}_{2} \mathrm{PdCl}_{4}$ synthesized from $\mathrm{PdCl}_{2}$ in a reaction with excess $\mathrm{NaCl}$ [27-29]. Sterile $\mathrm{Na}_{2} \mathrm{PdCl}_{4}$ solution was added directly to the samples to achieve a final concentration of $0.5 \mathrm{mM}$. The sterility of the aqueous solutions of $\mathrm{Ag}\left(\mathrm{NH}_{3}\right)_{2} \mathrm{NO}_{3}$ and $\mathrm{Na}_{2} \mathrm{PdCl}_{4}$ was confirmed by the absence of growth on the complex agar medium LB.

\section{Sensitivity of Bacteria to Silver and Palladium Salts}

The sensitivity of fresh cell suspensions of the methylotrophic bacteria M. quaylei to silver and palladium salts was conducted in $1 \mathrm{~mL}$ liquid medium at room temperature $\left(24-26{ }^{\circ} \mathrm{C}\right)$ without mixing. After 20-min incubation, the cell suspension was plated on solid agar medium. The sensitivity level was determined by the decrease in the number of CFU of the treated samples compared to the CFU of the control suspensions.

\section{NPs Formation}

The generation of the biogenic AgNPs and PdNPs from the sterile salt solutions in all the experiments was conducted in $50-\mu \mathrm{L}$ reaction mixtures with aliquots of cell suspension samples within $20 \mathrm{~min}$, at $\mathrm{pH} \mathrm{7-7.2} \mathrm{and} \mathrm{temperature} \mathrm{of}$ $24-26{ }^{\circ} \mathrm{C}$.

Five microliters of the reaction mixture was transferred to the grids for transmission electron microscopy. After 5 min of sorption of the cells and NPs, the liquid was removed, and the grids were washed five times with double-distilled water and dried for $15 \mathrm{~h}$. Aliquots of the samples from which the microorganisms were removed by centrifugation $(10,000 \times g, 25$ $\mathrm{min}$ ) were used as the control $[18,19]$. The absence of bacteria in the centrifuged control samples was confirmed by electron microscopy and by the absence of growth on MQ and LB agar media. The absence of NPs in the solutions and samples was confirmed by transmission electron microscopy. The scheme of the experiment is shown in Fig. 1.

\section{Transmission Electron Microscopy}

The study of the morphology, linear sizes, and localization of nanoparticles was performed using transmission electron microscopy (TEM). Electron microscopy and X-ray microanalysis of the specimens were conducted using a JEM-1400 microscope (JEOL, Japan) equipped with an X-ray microanalyzer (Oxford Instruments, UK) at an accelerating voltage of $80 \mathrm{keV}$. The specimens were prepared using standard copper grids covered with Formvar and reinforced with carbon.

\section{X-ray Diffraction Analysis}

The X-ray diffraction analysis (XRD) of NPs was fulfilled using XRD-6000 diffractometer (Shumadzu, Japan) under following conditions: $\mathrm{Cu} \mathrm{K} \alpha_{1}$ irradiation in the range of $2 \theta$ angles from $30^{\circ}$ to $80^{\circ}$ with a step of $0.02^{\circ}$ and exposure of $30 \mathrm{~s}$ at a point. The samples were previously dried and triturated in an agate mortar. Metallic silver and palladium were identified by the peaks in accordance with JCPDS 04-0783 for $\mathrm{Ag}^{0}$ and JCPDS 05-0681 for $\mathrm{Pd}^{0}$.

\section{Determination of NP Sizes}

The size distribution of NPs and their characteristics were determined using TEM with the subsequent processing and analysis of images using LabVIEW IMAQ Vision (National Instruments, USA), and the analysis took into account no less than 1000 NPs.

\section{Results}

\section{Streptomycin Resistance of Cells from Two Strains of $M$. quaylei}

The streptomycin-resistant mutant M. quaylei $\mathrm{SM}^{\mathrm{R}}$ was obtained earlier with protection from contamination during the mass cultivation of $M$. quaylei wild-type $\mathrm{MT}^{\mathrm{T}}$ bacteria. For the parent strain of the wild-type M. quaylei $\mathrm{MT}^{\mathrm{T}}$, the $\mathrm{LD}_{50}$ concentration of streptomycin is $0.005-0.01 \mathrm{mg} \mathrm{mL}^{-1}$, while the resistant mutant M. quaylei $\mathrm{SM}^{\mathrm{R}}$ grows up to a concentration of $4 \mathrm{mg} \mathrm{mL}^{-1}$ in the presence of this antibiotic.

The pleiotropic character of the streptomycin resistance mutation of M. quaylei $\mathrm{SM}^{\mathrm{R}}$ strain is manifested in the difference in properties of the surface biopolymers of cells. In the cells of the mutant $M$. quaylei $\mathrm{SM}^{\mathrm{R}}$, there was a fivefold decrease in the secretion of exopolysaccharides, primarily down to $0.2 \mathrm{~g} \mathrm{~L}^{-1}$, while in the parent culture of M. quaylei $\mathrm{MT}^{\mathrm{T}}$, this value was $1.05 \mathrm{~g} \mathrm{~L}^{-1}$. The values of the $\zeta$-potential for the cultures of M. quaylei $\mathrm{MT}^{\mathrm{T}}$ and M. quaylei $\mathrm{SM}^{\mathrm{R}}$ are negative throughout the entire $\mathrm{pH}$ range, which indicates a negatively charged cell surface. In addition, the culture of $M$. quaylei $\mathrm{SM}^{\mathrm{R}}$ is characterized by a low hydrophobicity of the cell surface $(5.5 \%)$ compared to the increased hydrophobicity of the surface in the cells of the original strain (39\%) (Table 1).

The determination of the cell sensitivity of $M$. quaylei strains to silver and palladium salts was conducted in liquid synthetic growth medium with methanol, i.e., under 
Fig. 1 Experiments on the generation of silver and palladium NPs with different strains of $M$. quaylei. a To obtain nanoparticles, the salts of $\mathrm{Ag}^{+}$or $\mathrm{Pd}^{2+}$ were added to suspensions of M. quaylei $\mathrm{MT}^{\mathrm{T}}$ of wild type (w.t.). b To obtain a streptomycinresistant mutant of $M$. quaylei $\mathrm{SM}^{\mathrm{R}}$, the strain of $M$. quaylei $\mathrm{MT}^{\mathrm{T}}$ was used. c To obtain nanoparticles, the salts of $\mathrm{Ag}$ or Pd were added to suspensions of M. quaylei $\mathrm{SM}^{\mathrm{R}}$. d In the control variants, the salts of $\mathrm{Ag}^{+}$or $\mathrm{Pd}^{2+}$ were added to the sterile growth medium. The pictures of NPs formed are shown to the right

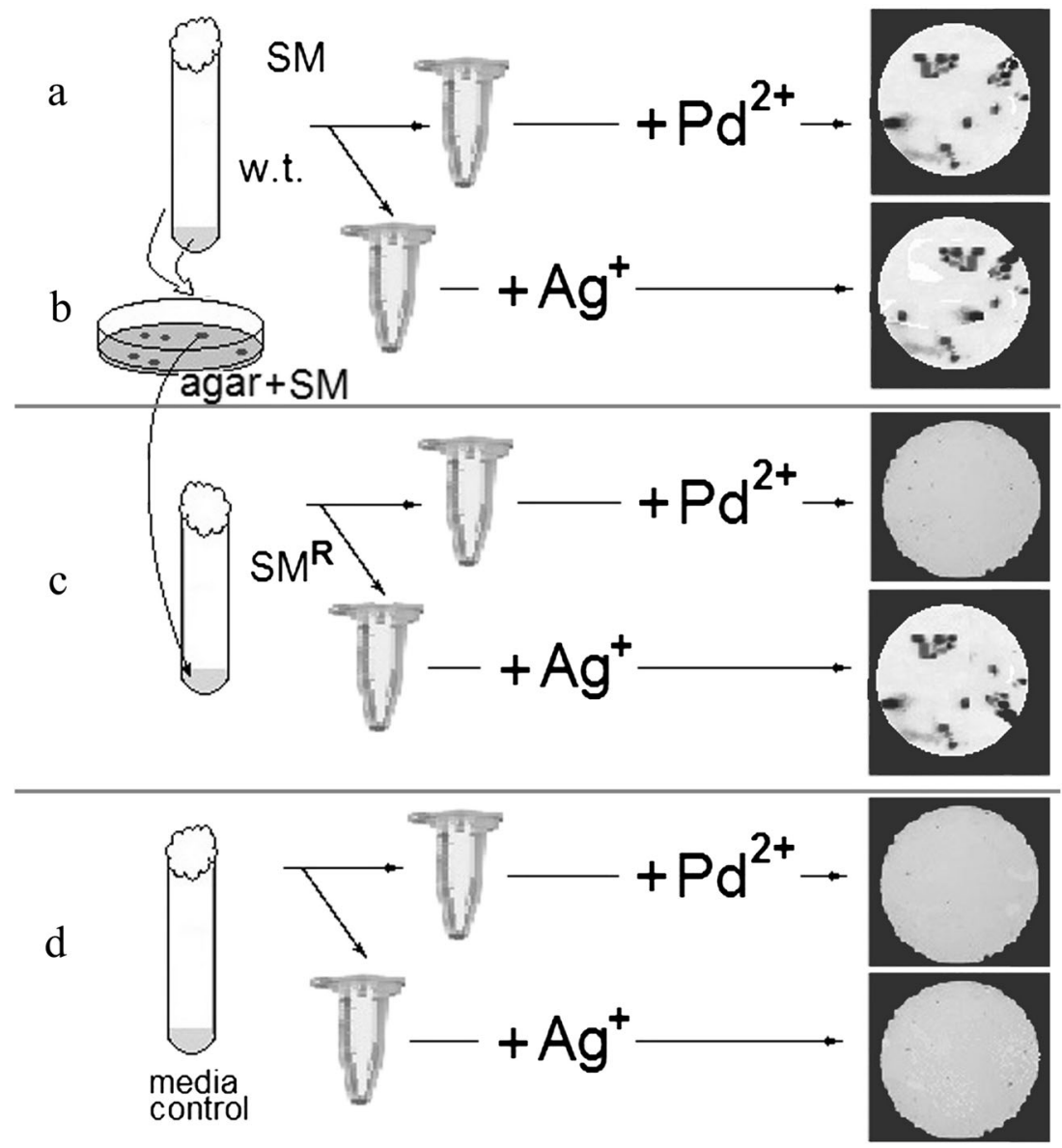

conditions corresponding to those in which NP generation was performed with these metals. The survival of the bacteria in a $0.1 \mathrm{mM}$ solution of $\mathrm{Ag}\left(\mathrm{NH}_{3}\right)_{2} \mathrm{NO}_{3}$ was $32 \%$ and $0.4 \%$ for the M. quaylei strains $\mathrm{MT}^{\mathrm{T}}$ and $\mathrm{SM}^{\mathrm{R}}$, respectively. When $0.5 \mathrm{mM} \mathrm{Na}_{2} \mathrm{PdCl}_{4}$ solution was added to the suspension of bacteria, the survival of the M. quaylei $\mathrm{MT}^{\mathrm{T}}$ and $\mathrm{SM}^{\mathrm{R}}$ strains was reduced to $5 \%$ and $59 \%$, respectively (Table 1).

\section{Generation of Silver and Palladium NPs with the Obligate Methylotrophic Bacterium M. quaylei}

Experiments on the synthesis of the NPs were conducted with actively growing cells, which were grown in a liquid synthetic growth medium with methanol and were taken directly from the flasks. The formation of nanoparticles was carried out by "green synthesis," that is, directly in the culture medium with cells in the logarithmic growth phase. Under such conditions, both the cells themselves (their surface biopolymers) and the compounds secreted by the cells can play the role of cation reducing agents in situ.

Both cultures of methylotrophic M. quaylei could form $\mathrm{Ag}^{\circ} \mathrm{NPs}$ when a sterile solution of $\mathrm{Ag}\left(\mathrm{NH}_{3}\right)_{2} \mathrm{NO}_{3}$ was added to the suspension. $\mathrm{The}^{\mathrm{Ag}} \mathrm{g}^{\circ} \mathrm{NP}$ sizes in the suspension of the wild-type M. quaylei $\mathrm{MT}^{\mathrm{T}}$ culture cells were from 16 to 100 $\mathrm{nm}$, with the primary fraction of $45 \mathrm{~nm}$. At the same time, in the presence of cells of the streptomycin-resistant mutant M. quaylei $\mathrm{SM}^{\mathrm{R}}, \mathrm{Ag}^{\circ} \mathrm{NPs}$ from 25 to $120 \mathrm{~nm}$ in size with the primary fraction of approximately $70 \mathrm{~nm}$ were formed (Figs. 2, 3, and 4).
Table 1 Difference in the characteristics of nanoparticles and their synthesis in pair of isogenic strains

\begin{tabular}{lllll}
\hline Characteristics of cultures & M. quaylei $\mathrm{MT}^{\mathrm{T}}$ & \multicolumn{2}{l}{ M. quaylei $\mathrm{SM}^{\mathrm{R}}$} & \\
\hline EPS secretion, g L & & & 0.2 & \\
Cell surface hydrophobicity, \% & 39 & 5.5 & \\
Characteristics of process & Average NPs & Cell survival, \% & Average NPs & Cell survival, \% \\
& size, nm & & size, nm & 0.4 \\
$\mathrm{Ag}^{+} \rightarrow \mathrm{Ag}^{\circ} \mathrm{NPs}$ & 45 & 32 & 70 & 59 \\
$\mathrm{Pd}^{2+} \rightarrow \mathrm{Pd}^{\circ} \mathrm{NPs}$ & No PdoNPs & 5 & 70 & 59 \\
\hline
\end{tabular}




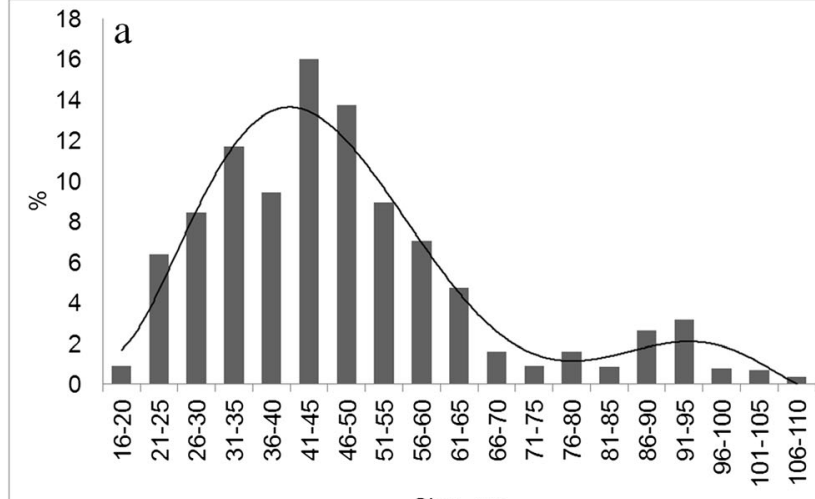

Size, $\mathrm{nm}$

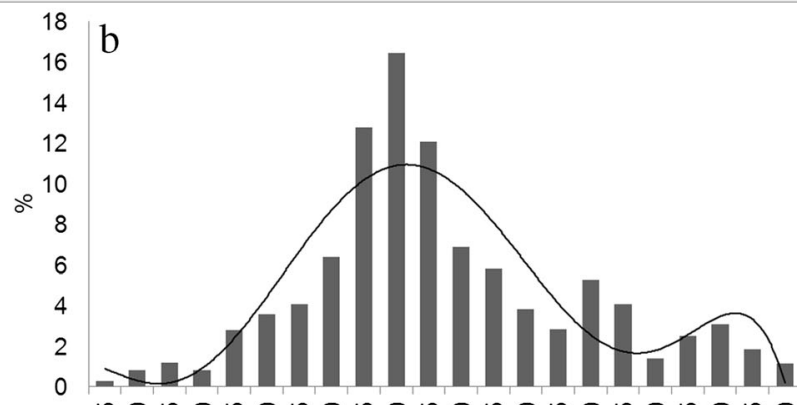

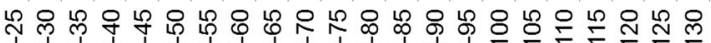

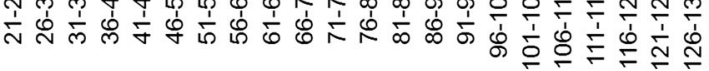

Size, $\mathrm{nm}$

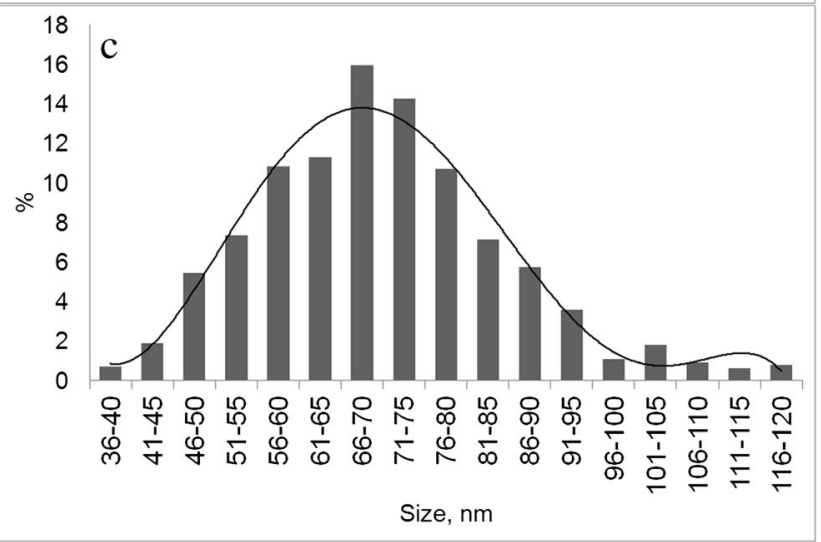

Fig. 2 Size distribution of $\mathrm{Ag}^{\circ} \mathrm{NPs}$ obtained with M. quaylei $\mathrm{MT}^{\mathrm{T}}(\mathbf{a})$ and M. quaylei $\mathrm{SM}^{\mathrm{R}}(\mathbf{b})$ and size distribution of $\mathrm{Pd}^{\circ} \mathrm{NPs}$ obtained with M. quaylei $\mathrm{SM}^{\mathrm{R}}(\mathbf{c})$
When a sterile solution of $\mathrm{Na}_{2} \mathrm{PdCl}_{4}$ was added to a suspension of M. quaylei methylotroph cells, $\mathrm{Pd}^{\circ} \mathrm{NPs}$ up to $70 \mathrm{~nm}$ in size were formed only in the presence of the streptomycin-resistant mutant M. quaylei $\mathrm{SM}^{\mathrm{R}}$ (Figs. 2, 5, and 6). In the culture of the wild-type M. quaylei $\mathrm{MT}^{\mathrm{T}}$, a significant number of optically opaque nanoscale objects were observed, which did not contain palladium according to X-ray microanalysis.

\section{Discussion}

The study of the mechanisms of the antibiotic resistance of certain microorganisms remains a topic of medicine, molecular biology, and microbiology [16, 30-32]. The fact that the surface structures of the cells play a key role in the resistance to most antibiotics has been revealed for many types of microorganisms. In addition, studies devoted to the comparative study of cell resistance to the toxic effects of salts and the corresponding metal NPs on the pure cultures of various microorganisms were conducted [33-36]. It should be noted that one of the most informative techniques of the functional comparative studies of microbial cultures is the comparison of the properties of the isogenic pairs of microbial cultures. Isogenic pairs of cultures differ only by one feature, for example, modification by a mutation such as increased resistance to an antibiotic. However, this approach is generally not applied to the ability of isogenic cultures to form NPs [37, 38].

It was shown that the resistance to streptomycin in most isolates (up to $70-80 \%$ ) with such a phenotype $\left(\mathrm{SM}^{\mathrm{R}}\right)$ is determined by mutations affecting the bacterial ribosomal protein S12 and 16S rRNA, encoded by rpsL or $r r s$ and 7-methylguanosine $\left(\mathrm{m}^{7} \mathrm{G}\right)$ methyltransferase gid $\mathrm{B}$, respectively [30, 39, 40]. From the earliest studies, it was known that streptomycin-resistant derivatives are characterized by the pleiotropic nature of the manifestation of the mutations. In addition, streptomycin-resistant mutants often also showed additional unpredictable resistance to other antibiotics [41]. In this study, we compared for the first time the ability of a pair of isogenic cultures of the obligate methylotrophs
Fig. 3 TEM of M. quaylei $\mathrm{MT}^{\mathrm{T}}$ (a) and M. quaylei $\mathrm{SM}^{\mathrm{R}}(\mathbf{b})$ cells with silver NPs
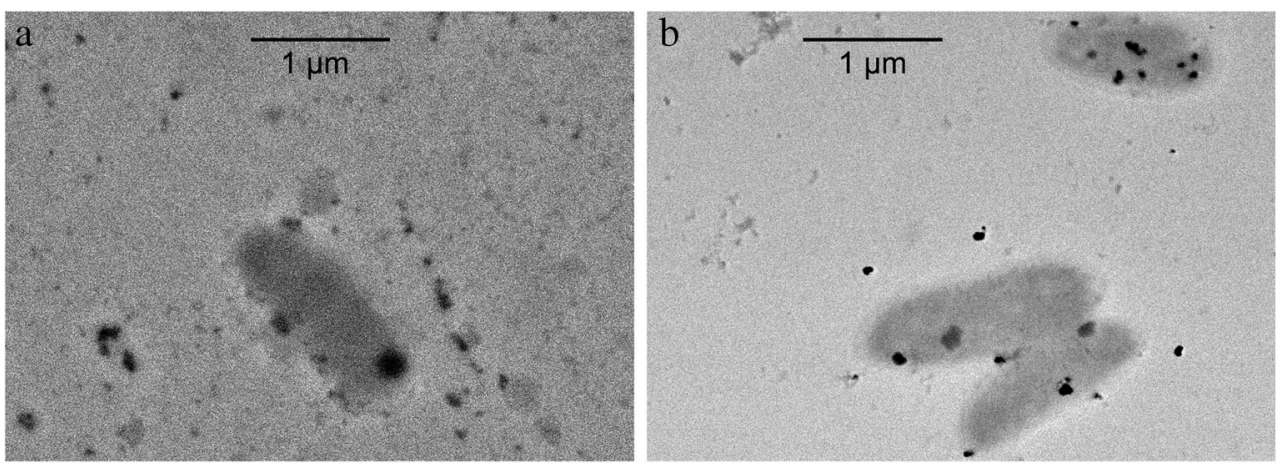


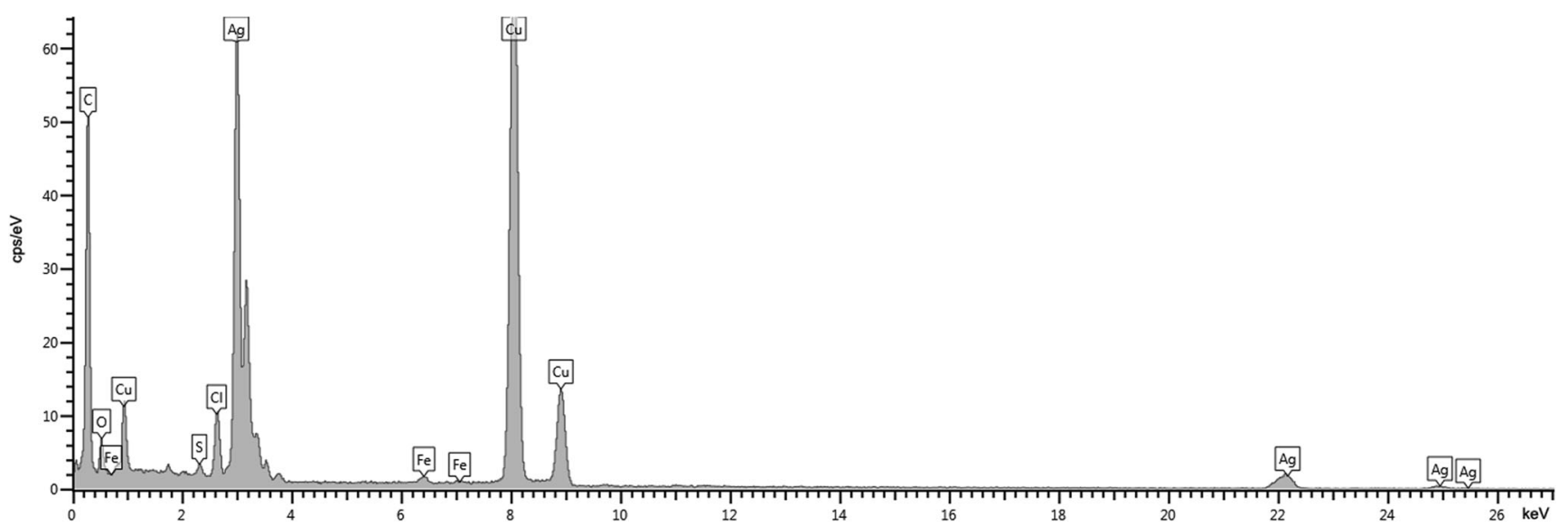

Fig. 4 Typical EDS spectrum from regions of Fig. 3 with $\mathrm{Ag}^{\circ} \mathrm{NPs}$

M. quaylei (one of which is a streptomycin-resistant derivative of the other) to protect against the biocidal influence of noble metal salts in a growth medium by the formation of biogenic nanoparticles. We compared the effect of silver $\mathrm{Ag}\left(\mathrm{NH}_{3}\right)_{2} \mathrm{NO}_{3}$ and palladium $\mathrm{Na}_{2} \mathrm{PdCl}_{4}$ salts on the cells and observed the formation of biogenic nanoparticles of reduced silver and palladium. The pleiotropic nature of the streptomycin resistance mutation in $M$. quaylei $\mathrm{SM}^{\mathrm{R}}$ was known previously [24]. The most noticeable differences were in the characters affecting the surface biostructures of the cells. These aspects include a fivefold decrease in the secretion of the exopolysaccharides (up to $0.2 \mathrm{~g} \mathrm{~L}^{-1}$ ) and an extremely low hydrophobicity of the cell surface $(5.5 \%)$ compared to the hydrophobicity of the cells of the original M. quaylei $\mathrm{MT}^{\mathrm{T}}$ strain, which is increased to $39 \%$ (Table 1). It was interesting to estimate the effect of such notable changes in the properties of the surface biopolymers of the M. quaylei cultures on the ability of the cells to reduce metal cations. For such comparisons of the reducing ability

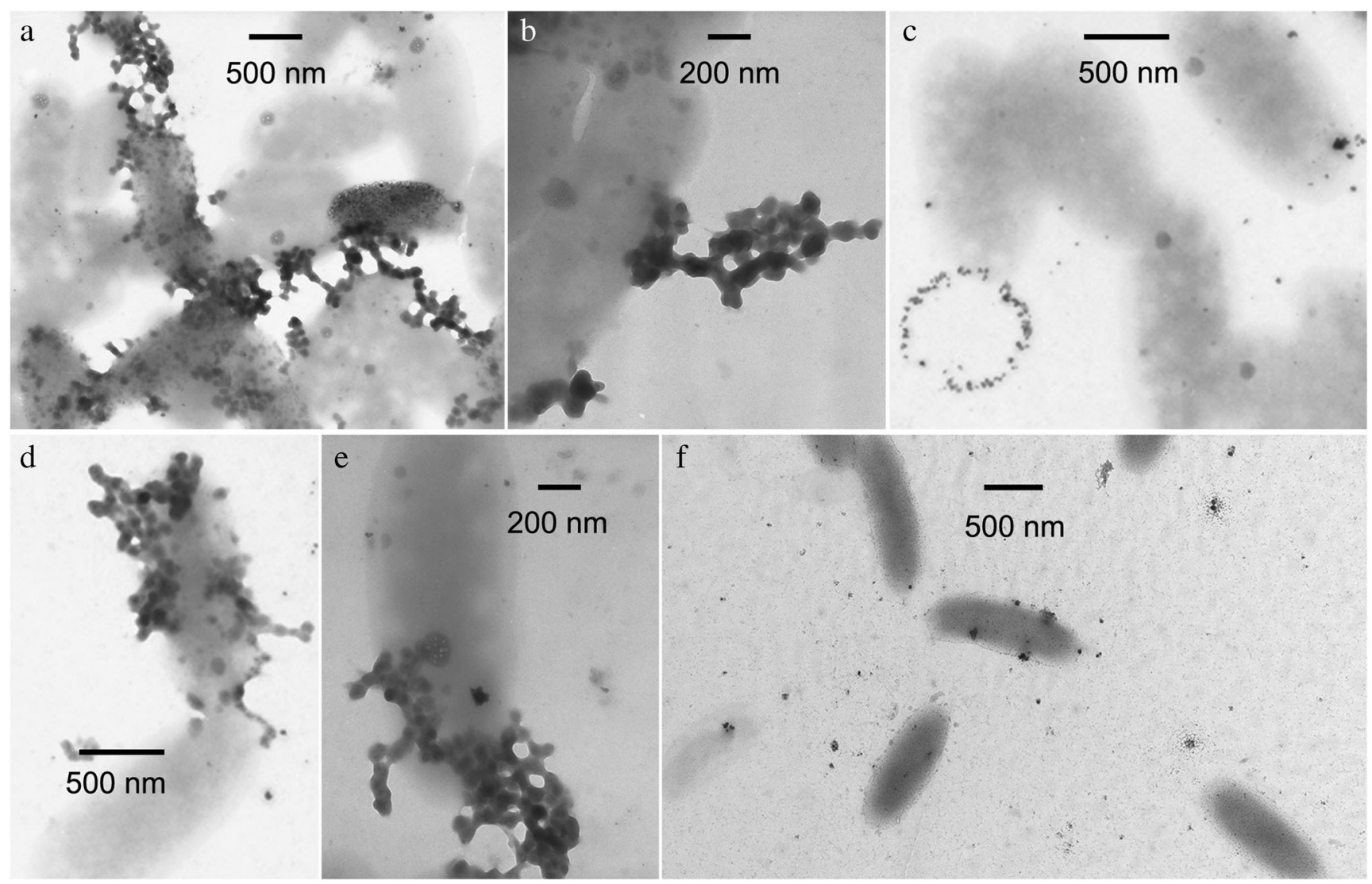

Fig. 5 TEM of M. quaylei $\mathrm{SM}^{\mathrm{R}}$ (a-e) cells with different palladium NPs clusters and TEM of M. quaylei $\mathrm{MT}^{\mathrm{T}}$ (f) cells with small structures without reduced palladium 


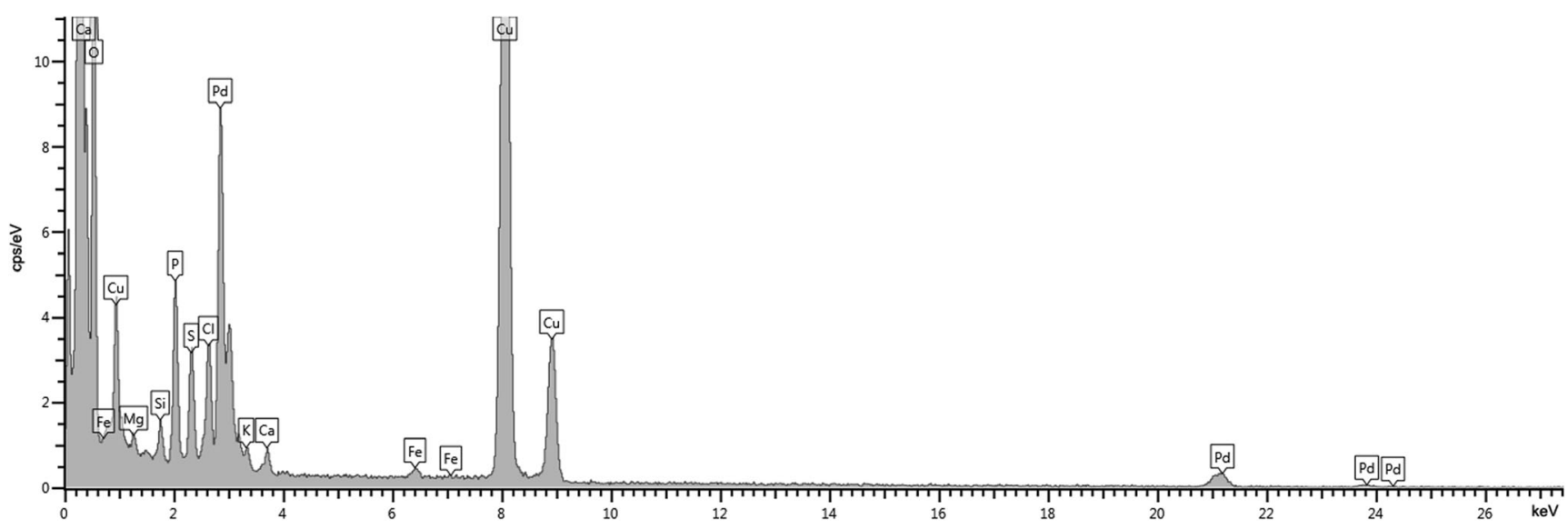

Fig. 6 Typical EDS spectrum from regions of Fig. 5 with PdºNs

of microorganisms, noble metals were chosen, primarily silver and palladium, which differ in the valency of the cations [42-44]. The use of the pair of obligate methylotrophic M. quaylei strains in the study appeared to be highly rational, since a simple synthetic medium was used to cultivate the bacteria. This medium does not contain a variety of organic compounds that may have reducing abilities and further affect the process of generating nanoparticles.

In preliminary experiments with methylotrophs, it was shown that at salt concentrations of $0.1 \mathrm{mM} \mathrm{Ag}\left(\mathrm{NH}_{3}\right)_{2} \mathrm{NO}_{3}$ and $0.5 \mathrm{mM} \mathrm{Na}_{2} \mathrm{PdCl}_{4}$, a sufficiently pronounced biocidal effect is achieved while maintaining the cell viability level acceptable for producing biogenic nanoparticles (Table 1). Under these conditions, for the first time, significant differences in the features of the formation of reduced silver and palladium nanoparticles in the presence of a pair of isogenic cultures of obligate methylotrophs directly in synthetic growth media with methanol were observed. Thus, in the streptomycin-resistant mutant M. quaylei $\mathrm{SM}^{\mathrm{R}}$, the intensive formation of palladium nanoparticles occurred. The average size of the $\mathrm{Pd}^{\circ} \mathrm{NPs}$ was 70 $\mathrm{nm}$. Most of these nanoparticles were adsorbed on cells or occurred in the form of chains that connected the individual cells together (Fig. 5a). In contrast, in the bacterial suspension of the original M. quaylei $\mathrm{MT}^{\mathrm{T}}$ strain, with a 20 -min contact with a solution of the palladium salt, there was a complete absence of biogenic palladium nanoparticles. This result occurred with the background decrease in the cell survival to 5\%. At the same time, a significant number of small structures were observed on the TEM image, in which there was no detectable number of atoms of the reduced palladium (Fig. 5f). Taking into account the pleiotropic nature of the streptomycinresistant mutation in M. quaylei $\mathrm{SM}^{\mathrm{R}}$ bacteria, it can be assumed that the actively synthesized exopolysaccharides of M. quaylei $\mathrm{MT}^{\mathrm{T}}$ very quickly come into contact with palladium ions Pd and therefore selectively block the formation of $\mathrm{Pd}^{\circ} \mathrm{NPs}$. This statement is supported by data on the high reactivity of $\mathrm{Pd}^{2+}$ cations towards biopolymers [45-47]. Thus, from the two isogenic cultures of methylotrophic bacteria, the ability to generate $\mathrm{Pd}^{\circ} \mathrm{NPs}$ manifests only in the streptomycinresistant M. quaylei $\mathrm{SM}^{\mathrm{R}}$.

Both cultures of methylotrophic bacteria can generate sufficiently large silver nanoparticles after the addition of $0.1 \mathrm{mM} \mathrm{Ag}\left(\mathrm{NH}_{3}\right)_{2} \mathrm{NO}_{3}$ solution for several minutes. Analysis of the size distribution showed that in the presence of wild-type cells, $\mathrm{Ag}^{\circ} \mathrm{NPs}$ have a size ranging from 16 to $100 \mathrm{~nm}$ with a bimodal distribution (with the primary
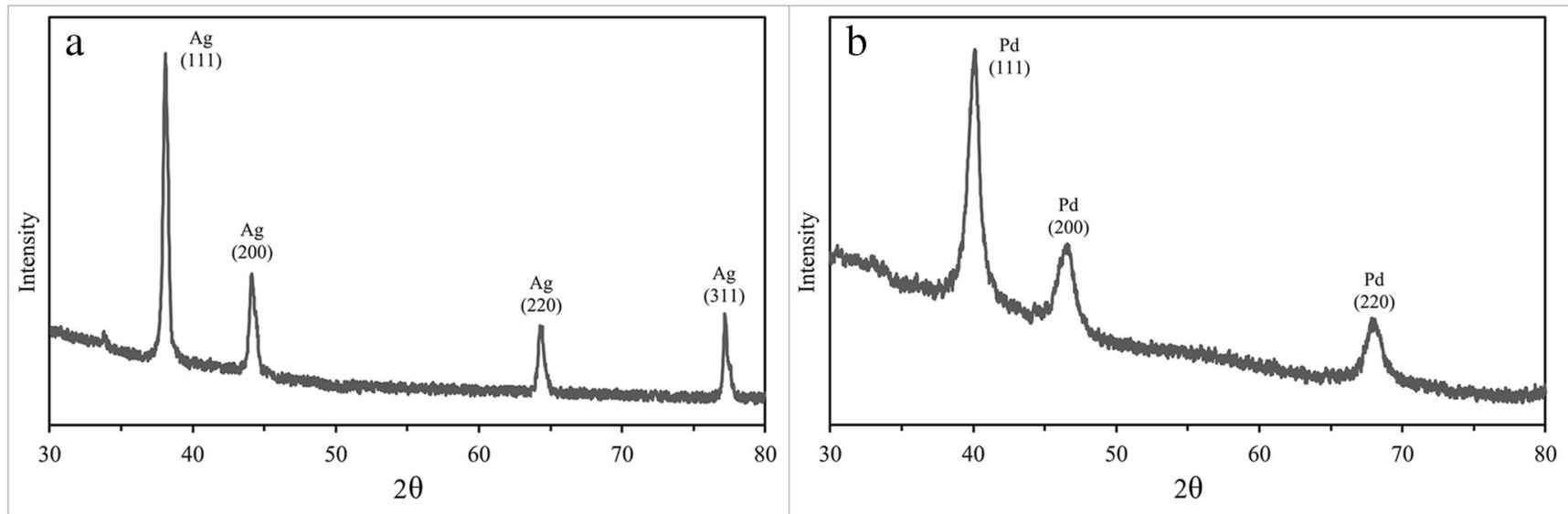

Fig. 7 XRD patterns typical for $\mathrm{Ag}^{\circ} \mathrm{NPs}$ obtained with M. quaylei $\mathrm{MT}^{\mathrm{T}}$ and M. quaylei $\mathrm{SM}^{\mathrm{R}}$ (a) and for Pd'NPs obtained with M. quaylei $\mathrm{SM}^{\mathrm{R}}$ (b) 
fraction $45 \mathrm{~nm}$ ). With the culture M. quaylei $\mathrm{SM}^{\mathrm{R}}$, nanoparticles are somewhat larger, predominantly ranging from 25 to $120 \mathrm{~nm}$ with a bimodal distribution and the primary fraction of approximately $70 \mathrm{~nm}$ (Figs. 2 and 3, Table 1). It is significant that most of the silver NPs are adsorbed on the cells or somehow associated with them. It can also be noted that the reduced secretion of exopolysaccharides and the extremely low hydrophobicity of the cell surface in the culture of M. quaylei $\mathrm{SM}^{\mathrm{R}}$ promote the formation of both silver and palladium nanoparticles (Table 1). The XRD patterns are shown in Fig. 7 and also confirmed the formation of $\mathrm{Ag}^{0}$ and $\mathrm{Pd}^{0} \mathrm{NPs}$ with face centered cubic (fcc) crystalline structure.

In general, this study shows for the first time the ability of obligate methylotrophic bacteria of the species $M$. quaylei to form noble metal nanoparticles; unlike the culture of the wild type (M. quaylei $\mathrm{MT}^{\mathrm{T}}$ ), the culture of the isogenic streptomycin-resistant mutant (M. quaylei $\mathrm{SM}^{\mathrm{R}}$ ) reduces and forms nanoparticles from both silver and palladium cations. Such a clear difference in the formation of biogenic silver and palladium nanoparticles (noble metals of differing cationic valences) indicates that the DBNG method allows researchers using several metals under similar conditions to distinguish very closely related cultures. This method would be an analog of a "variegated series" in the comparison of microbial species or cultures. It can be postulated that the assessment of the interaction of microbial cells with the salts of several metals may be useful for more complete characterization of closely related drug-resistant cultures of clinical isolates.

It has been shown that both cultures of the obligate methylotrophic bacteria M. quaylei (wild-type $\mathrm{MT}^{\mathrm{T}}$ culture and streptomycin-resistant mutant $\mathrm{SM}^{\mathrm{R}}$ ) can reduce silver salts and form $\mathrm{Ag}^{\circ} \mathrm{NPs}$ directly in a minimal synthetic medium with methanol as the only organic carbon source. In contrast to the wild-type culture, the isogenic streptomycinresistant mutant $M$. quaylei $\mathrm{SM}^{\mathrm{R}}$ can generate nanoparticles from reduced palladium atoms.

It can be expected that the assessment of the interaction of the microbial cells with various metal salts may be useful for more complete characterization of closely related drugresistant cultures of clinical isolates.

Acknowledgements Electron microscopy was carried out on the equipment of the UNIQEM Collection Core Facility, Research Center of Biotechnology of the Russian Academy of Sciences.

Authors' Contribution The contribution of all authors to the article is equal.

Funding Information The work was supported by Mendeleyev University of Chemical Technology of Russia, Project Number 0332018.

\section{Compliance with Ethical Standards}

Conflict of Interest The authors declare that they have no conflict of interest.

Open Access This article is distributed under the terms of the Creative Commons Attribution 4.0 International License (http:// creativecommons.org/licenses/by/4.0/), which permits unrestricted use, distribution, and reproduction in any medium, provided you give appropriate credit to the original author(s) and the source, provide a link to the Creative Commons license, and indicate if changes were made.

\section{References}

1. Anthony C, Williams P (2003) The structure and mechanism of methanol dehydrogenase. Biochim Biophys Acta, Proteins Proteomics 1647(1-2):18-23. https://doi.org/10.1016/S15709639(03)00042-6

2. Bennett RK, Steinberg LM, Chen W, Papoutsakis ET (2018) Engineering the bioconversion of methane and methanol to fuels and chemicals in native and synthetic methylotrophs. Curr Opin Biotechnol 50:81-93. https://doi.org/10.1016/j.copbio.2017.11. 010

3. Van Dien SJ, Lidstrom ME (2002) Stoichiometric model for evaluating the metabolic capabilities of the facultative methylotroph Methylobacterium extorquens AM1, with application to reconstruction of $\mathrm{C}_{3}$ and $\mathrm{C}_{4}$ metabolism. Biotechnol Bioeng 78(3):296-312. https://doi.org/10.1002/bit.10200

4. Whitaker WB, Sandoval NR, Bennett RK, Fast AG, Papoutsakis ET (2015) Synthetic methylotrophy: engineering the production of biofuels and chemicals based on the biology of aerobic methanol utilization. Curr Opin Biotechnol 33:165-175. https://doi.org/10. 1016/j.copbio.2015.01.007

5. Chistoserdova L (2018) Applications of methylotrophs: can single carbon be harnessed for biotechnology? Curr Opin Biotechnol 50: 189-194. https://doi.org/10.1016/j.copbio.2018.01.012

6. Pfeifenschneider J, Brautaset T, Wendisch VF (2017) Methanol as carbon substrate in the bio-economy: metabolic engineering of aerobic methylotrophic bacteria for production of value-added chemicals. Biofuels Bioprod Biorefin 11(4):719-731. https://doi. org $/ 10.1002 / b b b .1773$

7. Schrader J, Schilling M, Holtmann D, Sell D, Villela Filho M, Marx A, Vorholt JA (2009) Methanol-based industrial biotechnology: current status and future perspectives of methylotrophic bacteria. Trends Biotechnol 27(2):107-115. https://doi.org/10.1016/j. tibtech.2008.10.009

8. Yishai O, Lindner SN, de la Cruz JG, Tenenboim H, Bar-Even A (2016) The formate bio-economy. Curr Opin Chem Biol 35:1-9. https://doi.org/10.1016/j.cbpa.2016.07.005

9. Macaskie LE, Baxter-Plant VS, Creamer NJ, Humphries AC, Mikheenko IP, Mikheenko PM, Penfold DW, Yong P (2005) Applications of bacterial hydrogenases in waste decontamination, manufacture of novel bionanocatalysts and in sustainable energy. Biochem Soc Trans 33(1):76-79. https://doi.org/10.1042/ BST0330076

10. Durán N, Marcato PD, Durán M, Yadav A, Gade A, Rai M (2011) Mechanistic aspects in the biogenic synthesis of extracellular metal nanoparticles by peptides, bacteria, fungi, and plants. Appl Microbiol Biotechnol 90(5):1609-1624. https://doi.org/10.1007/ s00253-011-3249-8 
11. Durán M, Silveira CP, Durán N (2015) Catalytic role of traditional enzymes for biosynthesis of biogenic metallic nanoparticles: a minireview. IET Nanobiotechnol 9(5):314-323. https://doi.org/10.1049/ iet-nbt.2014.0054

12. Deplanche K, Bennett JA, Mikheenko IP, Omajali J, Wells AS, Meadows RE, Wood J, Macaskie LE (2014) Catalytic activity of biomass-supported Pd nanoparticles: influence of the biological component in catalytic efficacy and potential application in 'green' synthesis of fine chemicals and pharmaceuticals. Appl Catal B Environ 147:651-665. https://doi.org/10.1016/j.apcatb.2013.09. 045

13. Jung WK, Koo HC, Kim KW, Shin S, Kim SH, Park YH (2008) Antibacterial activity and mechanism of action of the silver ion in Staphylococcus aureus and Escherichia coli. Appl Environ Microbiol 74(7):2171-2178. https://doi.org/10.1128/AEM.0200107

14. Gadd GM (2010) Metals, minerals and microbes: geomicrobiology and bioremediation. Microbiol 156(3):609-643. https://doi.org/10. 1099/mic.0.037143-0

15. Tripathi DK, Tripathi A, Singh S, Singh Y, Vishwakarma K, Yadav G, Sharma S, Singh VK, Mishra RK, Upadhyay RG, Dubey NK, Lee Y, Chauhan DK (2017) Uptake, accumulation and toxicity of silver nanoparticle in autotrophic plants, and heterotrophic microbes: a concentric review. Front Microbiol 8:7. https://doi.org/ 10.3389/fmicb.2017.00007

16. Fonseca JD, Knight GM, McHugh TD (2015) The complex evolution of antibiotic resistance in Mycobacterium tuberculosis. Int $\mathrm{J}$ Infect Dis 32:94-100. https://doi.org/10.1016/j.ijid.2015.01.014

17. Martins M, Assunção A, Martins H, Matos AP, Costa MC (2013) Palladium recovery as nanoparticles by an anaerobic bacterial community. J Chem Technol Biotechnol 88(11):2039-2045. https://doi. org/10.1002/jctb.4064

18. Skladnev DA, Sorokin VV, Gal'chenko VF (2017) Formation of silver nanoparticles in water samples from Antarctic Lake Untersee. Microbiol 86(3):355-362. https://doi.org/10.1134/ S002626171703016X

19. Sorokin VV, Skladnev DA, Volkov VV, Tereshchenko EY, Mulukin AL, Gal'chenko VF (2013) The pathways of silver nanoparticles formation by Mycobacterium smegmatis. Dokl Biol Sci 452(1): 325-328. https://doi.org/10.1134/S0012496613050153

20. Klaus T, Joerger R, Olsson E, Granqvist CG (1999) Silver-based crystalline nanoparticles, microbially fabricated. Proc Natl Acad Sci 96(24):13611-13614. https://doi.org/10.1073/pnas.96.24.13611

21. Birla SS, Tiwari VV, Gade AK, Ingle AP, Yadav AP, Rai MK (2009) Fabrication of silver nanoparticles by Phoma glomerata and its combined effect against Escherichia coli, Pseudomonas aeruginosa and Staphylococcus aureus. Lett Appl Microbiol 48(2):173-179. https://doi.org/10.1111/j.1472-765X.2008.02510.x

22. Cao YL, Ding XL, Li HC, Yi ZG, Wang XF, Zhu JJ, Kan CX (2011) Morphology-controllable noble metal nanoparticles: synthesis, optical property and growth mechanism. Acta Phys -Chim Sin 27(6):1273-1286. https://doi.org/10.3866/PKU.WHXB20110604

23. Pereira L, Mehboob F, Stams AJ, Mota MM, Rijnaarts HH, Alves MM (2015) Metallic nanoparticles: microbial synthesis and unique properties for biotechnological applications, bioavailability and biotransformation. Crit Rev Biotechnol 35(1):114-128. https://doi.org/ 10.3109/07388551.2013.819484

24. Doronina N, Ivanova E, Trotsenko Y, Pshenichnikova A, Kalinina E, Shvets V (2005) Methylophilus quaylei sp. nov., a new aerobic obligately methylotrophic bacterium. Syst Appl Microbiol 28(4): 303-309. https://doi.org/10.1016/j.syapm.2005.02.002

25. Weisburg WG, Barns SM, Pelletier DA, Lane DJ (1991) 16S ribosomal DNA amplification for phylogenetic study. J Bacteriol 173(2):697-703. https://doi.org/10.1128/jb.173.2.697-703.1991

26. Le AT, Huy PT, Tam PD, Huy TQ, Cam PD, Kudrinskiy AA, Krutyakov YA (2010) Green synthesis of finely-dispersed highly bactericidal silver nanoparticles via modified Tollens technique. Curr Appl Phys 10(3):910-916. https://doi.org/10.1016/j.cap. 2009.10.021

27. Lloyd JR, Yong P, Macaskie LE (1998) Enzymatic recovery of elemental palladium by using sulfate-reducing bacteria. Appl Environ Microbiol 64(11):4607-4609

28. De Corte S, Hennebel T, De Gusseme B, Verstraete W, Boon N (2012) Bio-palladium: from metal recovery to catalytic applications. Microb Biotechnol 5(1):5-17. https://doi.org/10.1111/j. 1751-7915.2011.00265.x

29. Bennett JA, Mikheenko IP, Deplanche K, Shannon IJ, Wood J, Macaskie LE (2013) Nanoparticles of palladium supported on bacterial biomass: new re-usable heterogeneous catalyst with comparable activity to homogeneous colloidal Pd in the Heck reaction. Appl Catal B Environ 140:700-707. https://doi.org/10.1016/j. apcatb.2013.04.022

30. Smittipat N, Juthayothin T, Billamas P, Jaitrong S, Rukseree K, Dokladda K, Chaiyasirinroje B, Disratthakit A, Chaiprasert A, Mahasirimongkol S, Yanai H, Yamada N, Tokunaga K, Palittapongarnpim P (2016) Mutations in rrs, rpsL and gidB in streptomycin-resistant Mycobacterium tuberculosis isolates from Thailand. J Glob Antimicrob Resist 4:5-10. https://doi.org/10. 1016/j.jgar.2015.11.009

31. Brown ED, Wright GD (2016) Antibacterial drug discovery in the resistance era. Nat 529(7586):336-343. https://doi.org/10.1038/ nature 17042

32. de Sousa JM, Balbontín R, Durão P, Gordo I (2017) Multidrugresistant bacteria compensate for the epistasis between resistances. PLoS Biol 15(4):e2001741. https://doi.org/10.1371/journal.pbio. 2001741

33. Feris K, Otto C, Tinker J, Wingett D, Punnoose A, Thurber A, Kongara M, Sabetian M, Quinn B, Hanna C, Pink D (2009) Electrostatic interactions affect nanoparticle-mediated toxicity to gram-negative bacterium Pseudomonas aeruginosa PAO1. Langmuir 26(6):4429-4436. https://doi.org/10.1021/la903491z

34. Hessler CM, Wu MY, Xue Z, Choi H, Seo Y (2012) The influence of capsular extracellular polymeric substances on the interaction between $\mathrm{TiO}_{2}$ nanoparticles and planktonic bacteria. Water Res 46(15):4687-4696. https://doi.org/10.1016/j.watres.2012.06.009

35. Kasemets K, Suppi S, Künnis-Beres K, Kahru A (2013) Toxicity of $\mathrm{CuO}$ nanoparticles to yeast Saccharomyces cerevisiae BY4741 wild-type and its nine isogenic single-gene deletion mutants. Chem Res Toxicol 26(3):356-367. https://doi.org/10.1021/ tx300467d

36. Kędziora A, Speruda M, Krzyżewska E, Rybka J, Łukowiak A, Bugla-Płoskońska G (2018) Similarities and differences between silver ions and silver in nanoforms as antibacterial agents. Int $\mathrm{J}$ Mol Sci 19(2):444. https://doi.org/10.3390/ijms 19020444

37. Dehner CA, Barton L, Maurice PA, DuBois JL (2010) Sizedependent bioavailability of hematite $\left(\alpha-\mathrm{Fe}_{2} \mathrm{O}_{3}\right)$ nanoparticles to a common aerobic bacterium. Environ Sci Technol 45(3):977-983. https://doi.org/10.1021/es102922j

38. Ng CK, Sivakumar K, Liu X, Madhaiyan M, Ji L, Yang L, Tang C, Song H, Kjelleberg S, Cao B (2013) Influence of outer membrane c-type cytochromes on particle size and activity of extracellular nanoparticles produced by Shewanella oneidensis. Biotechnol Bioeng 110(7):1831-1837. https://doi.org/10.1002/bit.24856

39. Vladimirov AV, Bartoshevich I (1976) Pleiotropic effect of the mutation of streptomycin resistance in Micromonospora purpurea var. violacea. Antibiotiki 21(12):1066-1072

40. Hlaing YM, Tongtawe P, Tapchaisri P, Thanongsaksrikul J, Thawornwan U, Archanachan B, Srimanote P (2017) Mutations in streptomycin resistance genes and their relationship to streptomycin resistance and lineage of Mycobacterium tuberculosis Thai isolates. Tuberc Respir Dis 80(2):159-168. https://doi.org/10.4046/ $\operatorname{trd}$.2017.80.2.159 
41. Trindade S, Sousa A, Xavier KB, Dionisio F, Ferreira MG, Gordo I (2009) Positive epistasis drives the acquisition of multidrug resistance. PLoS Genet 5(7):e1000578. https://doi.org/10.1371/journal. pgen. 1000578

42. Renaud G, Lazzari R, Revenant C, Barbier A, Noblet M, Ulrich O, Leroy F, Jupille J, Borensztein Y, Henry CR, Deville JP, Scheurer F, Mane-Mane J (2003) Fruchart O, Real-time monitoring of growing nanoparticles. Sci 300(5624):1416-1419. https://doi.org/10.1126/ science. 1082146

43. Mukherjee P, Roy M, Mandal BP, Dey GK, Mukherjee PK, Ghatak J, Tyagi AK, Kale SP (2008) Green synthesis of highly stabilized nanocrystalline silver particles by a non-pathogenic and agriculturally important fungus $T$. asperellum. Nanotechnol 19(7):075103. https://doi.org/10.1088/0957-4484/19/7/075103

44. Pereira AR, Iost RM, Martins MV, Yokomizo CH, da Silva WC, Nantes IL, Crespilho FN (2011) Molecular interactions and structure of a supramolecular arrangement of glucose oxidase and palladium nanoparticles. Phys Chem Chem Phys 13(26):12155-12162. https://doi.org/10.1039/c1cp20432g
45. Kalaiselvi A, Roopan SM, Madhumitha G, Ramalingam C, Elango G (2015) Synthesis and characterization of palladium nanoparticles using Catharanthus roseus leaf extract and its application in the photo-catalytic degradation. Spectrochim. Acta A 135:116-119. https://doi.org/10.1016/j.saa.2014.07.010

46. Fang G, Li W, Shen X, Perez-Aguilar JM, Chong Y, Gao X, Chai Z, Chen C, Ge C, Zhou R (2018) Differential Pd-nanocrystal facets demonstrate distinct antibacterial activity against Gram-positive and Gram-negative bacteria. Nat Commun 9(1):129. https://doi. org/10.1038/s41467-017-02502-3

47. Leso V, Iavicoli I (2018) Palladium Nanoparticles: toxicological effects and potential implications for occupational risk assessment. Int J Mol Sci 19(2):503. https://doi.org/10.3390/ijms19020503

Publisher's Note Springer Nature remains neutral with regard to jurisdictional claims in published maps and institutional affiliations. 